\title{
Current Trends in the Development of Psycholinguistics in Russia
}

\author{
Valeria Aivazova \\ Surgut State University
}

\begin{abstract}
Correspondence concerning this article should be addressed to Valeria Aivazova, Department of Linguistics and Cross-cultural Communication, Surgut State University, 1 Lenina Street, Surgut, KhantiMansi Autonomous Region-Yugra, Russian Federation, 628400. E-mail: valeriya_aivazov@mail.ru
\end{abstract}

\begin{abstract}
The present review aims to acquaint the reader with some of the current trends in the development of Russian psycholinguistics. The variety of functions of a given language in society, its close relationship with communication, and a person's mental activity all conspire to determine the very flexible interaction of linguistics with corresponding social and psychological sciences. The close correlation of linguistics with psychology had given rise to the introduction of psychological methods and ideas in linguistics which essentially predetermined the emergence of psycholinguistics. Despite this, however, psycholinguistics shouldn't merely be considered as partly linguistics and partly psychology. Rather, it is a complex science which can be attributed both to linguistic (as it studies language) and psychological (as language is considered a psychological phenomenon) disciplines. And since language may be understood as a system of signs that serve society, psycholinguistics is necessarily included within the range of disciplines that examine social communication, including the registration and transfer of knowledge.
\end{abstract}

Keywords: psycholinguistics, identity, psycholinguistic research, self-identification, semiotics, discourse

The variety of functions of a given language in society, its close relationship with communication, and a person's mental activity all conspire to determine the very flexible interaction of linguistics with corresponding social and psychological sciences. The close correlation of linguistics with psychology has given rise to the introduction of psychological methods and ideas in linguistics, which essentially predetermined the emergence of psycholinguistics.

Despite this, however, psycholinguistics shouldn't merely be considered as partly linguistics and partly psychology. Rather, it is a complex science that can be attributed both to linguistic (as it studies language) and psychological (as language is considered a psychological phenomenon) disciplines. And since language may be understood as a system of signs that serve society, psycholinguistics is necessarily included within the range of disciplines that examine social communication, including the registration and transfer of knowledge. Subdivisions in psycholinguistics are also made based on the different components that make up human language. Linguistics-related areas include phonetics and phonology, which are concerned with the study of speech sounds. Within the scope of psycholinguistics, this research focuses on how the brain processes and understands these sounds. As for morphology, the study of word structures - especially the relationships between related words (such as dog and dogs) and the formation of words based on rules (such as plural formation) - within psycholinguistics a primary focus is on word recognition during reading. It aims to examine the processes involved in the extraction of orthographic, morphological, phonological, and semantic information from patterns in printed text. Pragmatic psycholinguistics concerns the role of context in the interpretation of meaning. A linguist interested in language production might conduct research on how words are prepared for speech, starting at the conceptual or semantic level.

As a science, psycholinguistics arose in the 1950's due to the emergence of practical problems that couldn't be solved by linguistics and traditional psychology. They included the issues of influencing 
society through speech, engineering psychology, and problems that occurred through the continuous study of foreign languages.

Speaking of the history of psycholinguistics, it emerged in the USSR in the 1960's. L. S. Vygotskii's Soviet school of psychology and linguistic traditions can be traced back to L. V. Shcherba. Soviet psycholinguistics regarded speech as a way of purposeful human behavior; it was considered subject to the general laws of the organization of activity.

A. A. Leontev, T. V. Riabova, I. A. Zimniaia, and E. M. Vereshchagin have studied the models of the grammatical generation of utterances. A. A. Brudnyi and A. P. Klimenko studied the mechanisms of perception and comprehension of the semantic aspects of speech, and the laws of the semantic organization of human linguistic capability in general have been researched by R. M. Frumkina. Still others have studied the probability of organization in the perception of speech. The major aspects of practical application lie in the fields of foreign language study, engineering and space psychology, the study of children's speech, and the study of the way speech influences people (radio, oratory, and so on).

Psycholinguistics is concerned with the nature of the computations and processes that the brain undergoes to comprehend and produce language. For example, the cohort model seeks to describe how words are retrieved from the mental lexicon when an individual hears or sees linguistic input. Recent research using non-invasive imaging techniques seeks to shed light on just where certain language processes occur in the brain.

There are a number of unanswered questions in psycholinguistics, such as whether the human ability to use syntax is based on innate mental structures or emerges from interaction with other humans, and whether some animals can be taught the syntax of human language. Two other major subfields of psycholinguistics investigate first language acquisition, the process by which infants acquire language, and second language acquisition. In addition, it is much more difficult for adults to acquire second languages than it is for infants to learn their first language (bilingual infants are able to learn both of their native languages easily). Thus, sensitive periods may exist during which language can be learned readily. A great deal of research in psycholinguistics focuses on how this ability develops and diminishes over time. It also seems to be the case that the more languages one knows, the easier it is to learn more. The present review aims to acquaint the reader with some of the current trends in the development of Russian psycholinguistics.

TheoriesintheField of RussianPsycholinguistics
Some influential theories in the field of Russian psycholinguistics can be mentioned. Language acquisition is under consideration. There are essentially two schools of thought as to how children acquire or learn language, and there is still much debate as to which theory is the correct one.

The first theory states that all language must be learned by the child. The second view states that the abstract system of language cannot be learned, but that humans possess an innate language faculty, or an access to what has been called universal grammar. The view that language can be learned has had a recent resurgence inspired by emergentism. This observation challenges the "innate" view on the grounds that it is scientifically unfalsifiable; that is to say, it can't be tested. With the amount of computer power increasing, researchers have been able to simulate language acquisition using neural network models (Barinova, 2011).

These models provide evidence that there may, in fact, be sufficient information contained in the input to learn language, even syntax. If this is true, then an innate mechanism is no longer necessary to explain language acquisition.

Onequestionin therealmoflanguage comprehension is how people understand sentences as they read (also known as sentence processing). Experimental research has spawned a number of theories about the architecture and mechanisms of sentence comprehension. Typically these theories are concerned with what types of information contained in the sentence the reader can use to build meaning, and at what point in reading does that information become available to the reader. Issues such as "modular" versus "interactive" processing have been theoretical divides in the field.

The authors Valentin E. Goldin, Aleftina P. Sdobnova, in the latest issue of "The Questions of Psycholinguistics", use the words "loud" and "quiet" to describe the issue of uniform dependence and required match between traditional lexicographical and psycholinguistic representation of lexical meanings (Goldin \& Sdobnikova, 2014).

A modular view of sentence processing assumes that the stages involved in reading a sentence function independently in separate modules. These modulates have limited interaction with one another. For example, one influential theory of sentence processing, the garden-path theory (Chesnokov, 2011), states that syntactic analysis takes place first. Under this theory as the reader is reading a sentence, he or she creates the simplest structure possible in order to minimize effort and cognitive load. This is done without any input from semantic analysis or context-dependent information. Hence, in the sentence "The evidence examined by the lawyer turned out to be unreliable," by the time the reader gets to the word "examined" he or she has 
committed to a reading of the sentence in which the evidence is examining something because it is the simplest parse. This commitment is made despite the fact that it results in an implausible situation; we know that experience that evidence can rarely if ever examine something. Under this "syntax first" theory, semantic information is processed at a later stage. It is only later that the reader will recognize that her or she needs to revise the initial parse into one in which "the evidence" is being examined. In this example, readers typically recognize their misparse by the time they reach "by the lawyer" and must go back and reparse the sentence (Chesnokov, 2011). This reanalysis is costly and contributes to slower reading times.

In the latest issue of "The Questions of Psycholinguistics", the author Elena B. Chernyshova published the article, "Theoretical bases of research of the assessment in ordinary language consciousness". The article deals with the psychological, linguistic and psycholinguistic research foundations, valuable reflection of objective relations of different types, as well as presents the contents of the evaluation component of the core Russian language consciousness, identified in the material associative Russian dictionary (Chernyshova, 2014).

In contrast to a modular account, an interactive theory of sentence processing, such as a constraintbased lexical approach (Gritsenko, 2009), assumes that all available information contained within a sentence can be processed at any time. Under the interactive account, for example, the semantics of a sentence (such as plausibility) can come into play early on in order to help determine the structure of a sentence. Hence, in the sentence above, the reader would be able to make use of plausibility information in order to assume that "the evidence" is being examined instead of doing the examining. There are data to support both modular and interactive accounts; which account is the correct one is still up for debate.

Behavioral tasks are under constant consideration among Russian linguists. Many of the experiments conducted in psycholinguistics, especially earlier on, are behavioral in nature. In these types of studies, subjects are presented with linguistic stimuli and asked to perform an action. For example, they may be asked to make a judgment about a word (lexical decision), reproduce the stimulus, or name a visually presented word aloud). Reaction times to respond to the stimuli (usually on the order of milliseconds) and proportion of correct responses are the most often employed measures of performance in behavioral tasks. Such experiments often take advantage of priming effects, whereby a "priming" word or phrase appearing in the experiment can speed up the lexical decision for a related "target" word later. As an example of how behavioral methods can be used in psycholinguistics research, Lappo M. (2009) investigated word encoding using the lexical decision task. She asked participants to make decisions about whether two strings of letters were English words. Sometimes the strings would be actual English words requiring a "yes" response, and other times they would be nonwords requiring a "no" response. A subset of the licit words were related semantically (e.g., cat-dog) while others were unrelated (e.g., bread-stem). Lappo found that related word pairs were responded to faster when compared to unrelated word pairs. This facilitation suggests that semantic relatedness can facilitate word encoding.

In the latest issue of "The Questions of Psycholinguistics", the author E. F. Tarasov attempts to clarify the methodological grounds for the language consciousness studies for which the author proposes A. Leontev's general psychological activity theory. This theory develops the concept of sense cognition and the concept of recognition, explaining the sense image. The language consciousness theory has been developed to explain the processes of transition from a sense image and a consciousness image to the speech utterance (Tarasov, 2014).

Great attention has recently been paid to the problem of the essence of identity and the methods of its analysis in linguistic and psycholinguistic research (Barinova \& Gritsenko, 2014; Lappo, 2014; Shlyakhova, 2014; Kyuchukov \& de Villeirs, 2014; Kuznetsova, 2014).

The authors Barinov and Gritsenko note that in contemporary social theory, the ethnic group is considered not only as an established community, but one reflecting a conscious need on the part if its members to belong to a group- presented in individual or social imagination as a steady and reliable "house" (Solovyova, 2009).

The linguist-researcher $\mathrm{M}$. A. Lappo considers the concept of "identity": given its polysemy and a high degree of explanatory force, it has become crucial in all the sciences within the humanitarian sphere sociology, philosophy, psychology, cultural science, political science, etc.

The societal aspiration of integrity, constancy and transparency with regard to person's image is the cornerstone of various approaches to the phenomenon of identity. A person's selfdom (egoism) has to be obvious and transparent, with form equal in value to content. In addition, the person's behavior has to reflect his intensions and personal image. Finally, behavior must be predictable and constant.

Another research trend in contemporary Russian psycholinguistics is the search for the aspects of perspective identity and the related process of selfidentification (see the works of Yu. Antonyan, I. I. Valuytseva and G. T. Hukhuni, R. Vodak, E. I. Goroshko, L. I. Grishayeva, E. S. Gritsenko, V. M. Gromova, V. A. Dauletova, E. I. Dakhalayeva, 
T. van Deyk, L. V. Enina, E. N. Katanova, V. I. Karasik, V. B. Kashkin, O. V. Kashkina, N. A. Kupina, M. A. Lappo, E. V. Leonova, E. P. Matuzkova, I. A. Medvedeva, O. A. Mikhaylova, A. V. Olyanich, D. V. Osipov, E. S. Oshchepkova, M. N. Rassokh, N. A. Mishankina and Z. I. Rezanova, P. Riker, N. B. Slobodyanik, L. V. Tsurikova, E. V. Chepkina, I. V. Shalina, M. S. Shkolova, L. Dzh. Phillips and M. W. Jorgensen, etc.).

Having observed complex correlations between speech and consciousness as well as between language and cognition, linguists may now investigate the notion of asymmetry in the analysis of subtler phenomena such as self-presentation of the speaking subject, speech mask, and virtual identity.

The authors Nistratov A. A., Sinyachkin V. P. study the gender differences in perception of human value.

The semantic differential (SD) technique was used for the purposes of this research. Through the data analysis two clustering dendrograms were created, both for men and women. The analysis of two dendrograms enabled to see some similarities and differences in perception of human values between two genders. In addition, it showed the hierarchy of semantic network in the evaluation of stimuli. Moreover, the semantic space was constructed and the factor analysis method was used for gender matrixes (Nistratov \& Sinyachkin, 2014).

The emergence of new psycholinguistics research methods and topics continues with numerous studies devoted to a relatively new genre, that of Internet communication (Polyakova, 2014; Ivanova, 2014). Active use of information technologies at the beginning of the $20^{\text {th }}$ century and the rapid expansion in Internet use has drawn the attention of people working in a variety fields, including political leaders. An obvious result of this surge in Internet activity is that new language forms are actively changing many of the old ones (Morozova, 2014). For example, "political tweeting" - a new mode of communication made possible by the Twitter Internet service, has appeared. Twitter (English "to tweet", "to chirp", "to stir") represents a social network, an online service for maintaining microblogs which have become a new subject matter in psycholinguistics.

The author A. V. Kirillova discusses the specifics post-non-classical episteme as applied to linguistics and offers a methodological innovation - the dynamic object, which is defined as an interactive selfdeveloping, often politicized Internet phenomenon; observability and objectification of its dynamics is being provided by the technical capabilities of the Internet. The prospects of studying the dynamic object for the diagnosis of ethnic tensions in Internet communication are being shown (Kirillova, 2014).

Semiotic and psycholinguistic approaches to text interpretation are widespread in current psychological and linguistic sciences (Fedoseeva, 2014; Apuhtin, 2009; Belyanin, 2000). The problem of distinguishing between the images of the world in the consciousness of the author and the recipient is being explored (distinctions represent an obstacle for the translation of sense and successful communication). On the other hand, such problems as the detection of perceptual features of certain types and contents and methods that allow an adequate perception of the message are under investigation.

Work in the field of experimental research and social psycholinguistics is still being carried out (Mironova, 2014; Andreeva, 2009; Arutyunova, 2000). N. I. Mironova notes that a new interdisciplinary field of linguistic study - sociopsycholinguistics can be defined. This science's primary objects of study are language and speech, more specifically, subjectlinguistic competence as a function of psychological and social features and social context. Thus, "sociopsycholinguistics" offers a highly specialized perspective on a traditional linguistic object.

A significant amount of research is also currently devoted to psycholinguistic discourse (Chesnokov, 2014; Kartashkova, 2014; Butakova, 2014). Chesnokov (2014) describes the mental epicenter, motive, aim, strategies and tactics of vindictive discourse. The tactics of desecration as a structural component of the abovementioned type of activity has been illuminated, and indirect forms of presentation of these tactics are being analyzed.

In conclusion, it is clear that psycholinguistics continues to be an intense field of scientific inquiry in Russia, with new approaches and tendencies testifying to its relevance within the contemporary paradigm of linguistic research.

\section{References}

Apukhtin, V. B. (2000). Psiholingvisticheskiy metod analiza smyislovoy strukturyiteksta [Psycholinguistic method of the analysis of semantic structure of the text]. Moscow, Russia: Izd-vo Institut RJa AN SSSR.

Belyanin, V. P. (2000). Osnovyi psiholingvisticheskoy diagnostiki: Modeli mira $v$ literature [Bases of psycholinguistic diagnostics: World models in literature]. Moscow, Russia: Trivola.

Barinova, A. O. (2011). Reprezentatsiya etnichnosti $\mathrm{V}$ angliyskoy leksikografii [Representation of ethnicity in an English lexicography]. Byulleten NGLU. Yazyik i Kultura, 16, 11-18.

Chernyshova, E. B. (2014). Teoreticheskie osnovyi issledovaniya otsenki $\mathrm{v}$ obyidennom yazyikovom soznanii [Theoretical bases of research of the assessment in ordinary language consciousness]. Voprosyi Psiholingvistiki, 22, 36-46. 
Deryabin, V. S. (2011). Komi-permyaki segodnya: Osobennosti etnokulturnogo razvitiya [KomiPermyaks today: Features of ethnocultural development]. Rossiyskaya Akademiya Nauk, 10, 4456.

Chesnokov, I. I. (2011). Diskursivnaya taktika zlopozhelaniya: Pryamyie formyi ob'ektivatsii [Discursive tactics of desecration: Direct forms of objectivization]. Filologicheskie Nauki, 5, 76-85.

Neshchimenko, G. P. (Ed.) (2009). Globalizatsiyaetnizatsiya: Etnokulturnyie $i$ etnoyazyikovyie protsessyi[Globalization-etnization:Ethnocultural and ethnolanguage processes] (Vol. 1-2). Moscow, Russia: Sovet Rossiyskoy Akademii nauk.

Gritsenko, E. S. (2012). Globalnoe i lokalnoe v rechevyih praktikah molodezhnyih subkultur [Global and local in the speech of young subcultures]. Vestnik Moskovskogo Universiteta: Ser.19: Lingvistika $i$ Mezhkulturnaya Kommunikatsiya, 87-93.

Gritsenko, E. S. (2009). Zhenschinyi i zhenstvennost $\mathrm{v}$ amerikanskom predvyibornom diskurse [Women and feminity in the American pre-election discourse]. Vestnik Moskovskogo Universiteta: Ser.19: Lingvistika i Mezhkulturnaya Kommunikatsiya, 112123.

Goldin, V. E., \& Sdobnova, P. A. (2014). "Slovarnoe” i "psiholingvisticheskoe" predstavlenie znacheniy: Poiski sootvetstviy ["Lexicographical" and "psycholinguistic" representation of meaning: Search for a match]. Voprosyi Psiholingvistiki, 22, 56-67.

Hornby, A. S. (2010). Oxford Advanced Learner's Dictionary of Current English (8th ed.). Oxford, UK: Oxford University Press.

Ivanova, A. I. (2011). «Myi i Rossiya segodnya»: Lingvisticheskiy analiz tvitter-platformyi Prezidenta Dmitriya Medvedeva [We and Russia today: Linguistic analysis of the Twitter of the President Dmitry Medvedev]. Politicheskaya lingvistika. Retrived from http://journals.uspu.ru/i/ inst/ling/ling36/ling36_15.pdf

Kirilina, A. V. (2014). Ponyatie dinamicheskogo ob'ekta
V postneklassicheskoy lingvistike [The concept “dynamic object in non-classical linguistics"]. Voprosyi Psiholingvistiki, 22, 36-46.

Lappo, M.A. (2009). Yazyikovyie sredstva identifikatsii/ samoidentifikatsii kak nechetkie lingvisticheskie lingvisticheskie mnozhestva [Language means of identification/self-identification as indistinct (indistinct) linguistic sets]. In T. A. Tripolskaya (Ed.), Yazyik kak zhivaya sistema $v$ issledovatelskih paradigmah sovremennoy lingvistiki (pp. 92-102). Novosibirsk, Russia: Novosibirskij gosudarstvennyj pedagogicheskij universitet.

Nistratov, A. A., \& Sinyachkin, V. P. (2014). Gendernyie razlichiya vospriyatiya tsennostey [Gender differences in perception of human values]. Voprosyi Psiholingvistiki, 22, 94-102.

Pavlenko, A., Norton, B. (2007). Imagined communities, identity, and English language learning. In J. Cummins \& C. Davison (Eds.), International handbook of English language teaching (pp. 669680). New York, NY: Springer.

Sheygal, E. I. (2000). Semiotika politicheskogo diskursa [Semiotics of political discourse]. Volgograd, Russia: Volgogradskiy gosudarstvennyiy pedagogicheskiy universitet.

Solovyova, A. N. (2009). Kulturnyie razlichiya kak osnova etnicheskoy identichnosti $\mathrm{v}$ kontekste globalizatsii [Cultural distinctions as a basis of ethnic identity in the context of globalization]. Mir Psihologii, 3, 23-34.

Tatasov, E. F. (2014). Prolegomenyi k teorii yazyikovogo soznaniya [Prolegomens in the theory of language cognition]. Voprosyi Psiholingvistiki, 22, 24-27.

Tishkov, V. A. (2000). Designing of ethnic identity. Political anthropology. Course of lectures. New York, NY. Retrived from http://www.valerytishkov.ru/ cntnt/publikacii3/lekcii2/lekcii/konstruiro.html

Zalevskaya,A.A.(2009). Voprosyi psiholingvisticheskoy teorii dvuyazyichiya [Questions of the psycholinguistic theory of bilingualism]. Voprosyi Psiholingvistiki, 10, 10-17. 